\title{
Breast Cancer Risk Assessment and Risk Reduction
}

\author{
Lisa A. Newman, MD, MPH, FACS ${ }^{\mathrm{a}, *}$, \\ Victor G. Vogel, MD, MHS, FACP \\ ${ }^{\mathrm{a}}$ Breast Care Center, 1500 East Medical Center Drive, 3308 CGC, University \\ of Michigan, Ann Arbor, MI 48109, USA \\ ${ }^{\mathrm{b}}$ University of Pittsburgh Cancer Institute, Breast Cancer Prevention Program, \\ University of Pittsburgh School of Medicine, Magee-Womens Hospital, 300 Halket Street, \\ Room 3524 Pittsburgh, PA 15213-3180, USA
}

Until recently, the primary message of breast health awareness programs has been that early detection is a woman's best protection against breast cancer, because there was no way to prevent the disease. Currently, however, tamoxifen is approved by the Food and Drug Administration (FDA) for chemoprevention of breast cancer in high-risk women, and studies are underway to evaluate other medications that may decrease the risk of breast cancer. Data have also become available regarding the efficacy of surgical strategies to reduce breast cancer risk. Any prevention method, however, will have associated risk of complications or adverse effects, and determining the net risk/benefit ratio depends on the ability to quantify accurately a woman's baseline likelihood of developing breast cancer. This article reviews available methods for assessing and reducing risk breast cancer.

\section{Breast cancer risk assessment}

The most common means of estimating an individual woman's risk of developing breast cancer is by application of a statistical tool known as the Gail model. The Gail model was derived from data from an American Cancer Society study regarding feasibility of mammographic screening of the American female population, the Breast Cancer Detection and Demonstration Project (BCDDP). Breast cancer risk factors generated from a case control subset of BCDDP participants are combined with estimates of baseline risk

* Corresponding author.

E-mail address: lanewman@umich.edu (L.A. Newman). 
generated from the Surveillance, Epidemiology, and End Results (SEER) program incidence data to compute individualized, absolute estimates of breast cancer risk [1]. Risk factor components of the Gail model include age at time of counseling, age at menarche, age at first live birth, history of prior breast biopsies, and first-degree relatives who have breast cancer.

The Gail model was modified for determination of eligibility to participate in the National Surgical Adjuvant Breast Project (NSABP) chemoprevention trials, and the modified version was made available as a Web-based program (http://www.nci.nih.gov/bcrisktool/). These modifications allowed for prediction of invasive breast cancer only; they accounted for risk related to history of atypical hyperplasia; and they included adjustments to predict risk in African American women [2]. Women aged 35 years and older were deemed eligible to participate in the first chemoprevention trial if they had a 5 -year risk of at least $1.7 \%$.

Model accuracy for predicting number of breast cancers detected in independent cohorts of white American women has been validated in studies of screened Texas women [3], the Nurses' Health Study [4,5], and the placebo arm of the NSABP's first Breast Cancer Prevention Trial (BCPT) [2]. Limitations of the Gail model (and its modifications) include the facts that it does not account for paternal cancer history or the extended family cancer history, and its uncertain validity for assessing risk in non-white American women. Although the model is well-suited for identifying cohorts of women who are appropriate to participate in a chemoprevention trial, its discriminatory accuracy at the individual level has been assessed as modest [5].

Alternative strategies for estimating breast cancer risk have therefore been explored, such as random periareolar fine-needle aspiration biopsy (RPFNA) [6,7], ductal lavage [8], mammographic density [9,10], and endogenous hormone levels [11-13]. RPFNAs have limited applicability because of the invasive nature, ductal lavage enjoyed limited popularity because of the specialized training and equipment required, and measurement of circulating hormones is associated with substantial interlaboratory variability in technology. Mammographic density, however, has recently generated substantial enthusiasm as a powerful feature that can be incorporated into accurate breast cancer statistical models, with improved discriminatory accuracy compared with the standard Gail model [14,15]. Unfortunately, however, mammographic density is not a standardized component of routine mammographic reporting [16].

\section{Medical risk reduction with chemoprevention}

The ability to manipulate hormonally breast tissue and thereby reduce proliferative changes that would otherwise evolve into cancer has been recognized over the past several decades. Women using tamoxifen for a unilateral breast cancer were seen to have a $47 \%$ lower risk of second primary/ contralateral breast cancer compared with breast cancer patients not treated 
with tamoxifen. These data motivated implementation of the first large-scale chemoprevention trial conducted in the United States, the NSABP P-1 study [17]. This was a prospective, placebo-controlled, randomized study of tamoxifen in 13,880 high-risk women. Eligibility criteria to participate in the P-1 study included aged least 60 years; a 5-year Gail model breast cancer risk estimate of more than $1.66 \%$; and history of lobular carcinoma in situ (LCIS). After 54 months median follow-up, the trial was unblinded early because of the magnitude of difference in breast cancer incidence between the treated and control arms of the study, revealing that tamoxifen lowered breast cancer risk by $49 \%$. It is therefore now considered standard of care to evaluate breast cancer risk factor information in women and to counsel high-risk women about the options of chemoprevention.

Unfortunately, however, making a commitment to 5 years of tamoxifen is not easy, because several potentially severe adverse reactions can be associated with this therapy. Tamoxifen's effects on estrogen receptors in the uterus, vascular system, and central nervous system increase risks of uterine cancer, thromboembolic phenomena (deep vein thrombosis and pulmonary emboli), and vasomotor symptoms (eg, hot flashes, night sweats), respectively. Partially offsetting these risks are tamoxifen's estrogen agonist effects on the skeletal system and lipid profile, resulting in a reduced incidence of osteoporosis and lower serum cholesterol levels. NSABP P-1 study participants in the premenopausal age range were relatively protected from adverse tamoxifen effects [17]; however, the safety of tamoxifen during fetal development has not been established, and chemoprevention with this agent is therefore contraindicated in women who are contemplating pregnancy. Otherwise, tamoxifen has a favorable risk-benefit ratio in high-risk premenopausal women.

Complicating the chemoprevention decision process further is the fact that tamoxifen will only reduce the incidence of estrogen receptor-positive tumors. Tamoxifen has no impact on the occurrence of estrogen receptor-negative disease, a potentially significant issue in counseling women who harbor mutations in one of the breast cancer susceptibility genes. Subset analysis of geneticallytested NSABP P-1 participants demonstrated that tamoxifen does not reduce breast cancer risk in BRCA1 gene mutation carriers; however, it does appear to offer some chemoprevention benefit in BRCA2 mutation carriers [18]. This is consistent with prior studies revealing that BRCA2 mutation-associated tumors are similar in histopathology to sporadic breast cancer, whereas BRCA1 cancers are more likely to be estrogen receptor-negative and aneuploid.

The ideal selective estrogen receptor modulator (SERM) would retain antiproliferative activity in the breast, but without subjecting the patient to the negative risks. Raloxifene is a SERM that is approved by the FDA for management of postmenopausal osteoporosis, and preliminary evidence from its use in this setting suggested that it would have similar activity as tamoxifen in breast cancer prevention, but with fewer adverse effects. The NSABP's second chemoprevention trial, the Study of Tamoxifen and Raloxifene (STAR), randomized more than 19,000 high-risk postmenopausal 
Table 1

Phase III trials of breast cancer providing data on chemoprevention

\begin{tabular}{|c|c|c|c|c|c|c|c|c|}
\hline Study & $\begin{array}{l}\text { Primary } \\
\text { chemoprevention } \\
\text { study? }\end{array}$ & $\mathrm{N}$ & $\begin{array}{l}\text { Eligibility } \\
\text { criteria }\end{array}$ & Age range & Randomization & $\begin{array}{l}\text { Intended } \\
\text { treatment } \\
\text { duration } \\
\text { (years) }\end{array}$ & $\begin{array}{l}\text { Median } \\
\text { follow-up }\end{array}$ & $\begin{array}{l}\text { Breast } \\
\text { cancer hazard } \\
(95 \% \text { confidence } \\
\text { interval })\end{array}$ \\
\hline $\begin{array}{l}\text { Royal Marsden } \\
{[24,25]}\end{array}$ & Yes & 2471 & $\begin{array}{l}\text { High risk, family } \\
\text { history }\end{array}$ & $30-70$ & Tam versus placebo & $5-8$ & 70 months & $\begin{array}{c}1.06(0.7-1.7) \text { tam } \\
\text { versus placebo }\end{array}$ \\
\hline $\begin{array}{l}\text { NSABP P-01 } \\
{[17,24]}\end{array}$ & Yes & 13,388 & $\begin{array}{l}\geq 1.67 \% 5 \text {-year } \\
\quad \text { risk } \\
\text { LCIS } \\
\text { Age }>60 \text { years }\end{array}$ & $35-$ & Tam versus placebo & 5 & 54.6 months & $0.51(0.39-0.66)$ \\
\hline $\begin{array}{l}\text { Italian Tamoxifen } \\
\text { Study Group } \\
{[24,26-28]}\end{array}$ & Yes & 5408 & $\mathrm{~S} / \mathrm{p}$ hysterectomy & $35-70$ & Tam versus placebo & 5 & 81.2 months & $\begin{array}{l}\text { All: } 0.75(0.48-1.18) \\
\text { No HRT: } 0.99 \\
\quad(0.59-1.68) \\
\text { HRT: } 0.36 \\
\quad(0.14-0.91)\end{array}$ \\
\hline IBIS $[24,29]$ & Yes & 7139 & $\mathrm{RR}>2$ & $35-70$ & Tam versus placebo & 5 & 50 months & $0.68(0.50-0.92)$ \\
\hline $\begin{array}{l}\text { Tamoxifen } \\
\text { Chemoprevention } \\
\text { Overview } \\
\text { Analysis [24] }\end{array}$ & $\begin{array}{l}\text { Yes, collective } \\
\text { review }\end{array}$ & 28,406 & NA & NA & Tam versus placebo & NA & $\begin{array}{l}70.6 \times 10^{3} \\
\text { women } \\
\text { years }\end{array}$ & $0.62(0.54-0.72)$ \\
\hline MORE $[24,30]$ & No & 7705 & $\begin{array}{l}\text { Postmenopausal } \\
\text { osteoporosis }\end{array}$ & Median 66.5 & $\begin{array}{l}\text { Raloxifene versus } \\
\text { placebo }\end{array}$ & 4 & 36 months & $0.28(0.17-0.46)$ \\
\hline CORE [33] & Yes & 5213 & $\begin{array}{l}\text { Postmenopausal } \\
\text { osteoporosis }\end{array}$ & Mean 65.8 & $\begin{array}{l}\text { Raloxifene versus } \\
\text { placebo }\end{array}$ & 8 & 95 months & $0.34(0.18-0.66)$ \\
\hline STAR $[19,20,34]$ & Yes & 19,747 & $\begin{array}{l}\text { Postmenopausal; } \\
\geq 1.67 \% \text { 5-year } \\
\text { risk LCIS }\end{array}$ & Mean 58.5 & $\begin{array}{l}\text { Tam versus } \\
\text { raloxifene }\end{array}$ & 5 & 47 months & $\begin{array}{l}1.02(0.82-1.28) \\
\text { Tam versus } \\
\text { raloxifene; } \\
\text { invasive breast } \\
\text { cancer hazard }\end{array}$ \\
\hline
\end{tabular}




\begin{tabular}{|c|c|c|c|c|c|c|c|c|}
\hline $\begin{array}{l}\text { Fenritimide/ } \\
\text { 4-HPR [31] }\end{array}$ & Yes & 1574 & $\begin{array}{l}\text { Early-stage } \\
\text { unilateral } \\
\text { breast } \\
\text { cancer }\end{array}$ & $28-67$ & $4 \mathrm{HPR}$ versus placebo & $>5$ & 97 months & $\begin{array}{c}\text { Premenopausal: } \\
0.66 \text { (0.41-1.07) } \\
\text { Postmenopausal: } \\
1.32 \text { (0.82-2.15) }\end{array}$ \\
\hline $\begin{array}{c}\text { Tamoxifen } \\
\text { Adjuvant } \\
\text { Therapy } \\
\text { Overview } \\
\text { Analysis } \\
{[24,35]}\end{array}$ & No & 14,170 & $\begin{array}{l}\text { Operable } \\
\text { breast cancer }\end{array}$ & NA & $\begin{array}{l}\text { Tam versus } \\
\text { no adjuvant } \\
\text { therapy }\end{array}$ & $\begin{array}{l}\geq 5 \\
\quad \text { (average, } \\
\quad 5 \text { years) }\end{array}$ & 60 months & $0.54(0.43-0.69)$ \\
\hline ATAC [23] & No & 9366 & $\begin{array}{l}\text { Postmenopausal, } \\
\text { early-stage } \\
\text { breast cancer }\end{array}$ & $\begin{array}{l}\text { Mean } \\
\quad 64 \text { years }\end{array}$ & $\begin{array}{l}\text { Anastrozole } \\
\text { versus Tam } \\
\text { versus Tam }+ \\
\text { anastrozole }\end{array}$ & 5 & 33.3 months & $0.42(0.22-0.79)$ \\
\hline
\end{tabular}

The reader should note that the Royal Marsden Trial was designed statistically to develop pilot data for the IBIS trial. The Hazard Ratio for risk reduction in the ATAC Trial refers to reduction in risk of new contralateral primary breast cancer.

Abbreviations: ATAC, Anastrozole Alone or in Combination with Tamoxifen versus Tamoxifen Alone; CORE, Continuing Outcomes Relevant to Evista; HRT, hormone replacement therapy; IBIS, International Breast Cancer Intervention Study; MORE, Multiple Outcomes of Raloxifene Evaluation; Tam, tamoxifen; s/p, status post. 
women to receive one of these two SERMs for 5 years. Premenopausal women were ineligible for STAR participation because of the absence of data on raloxifene's effects in young, ovulating women.

Results of the STAR trial were released recently [19,20], demonstrating comparable effectiveness for tamoxifen and raloxifene in preventing invasive breast cancer (incidence 4.3 per 1000 versus 4.4 per 1000; relative risk (RR) 1.02 ; $95 \%$ confidence interval [CI], 0.82-1.28). Surprisingly, women randomized to receive raloxifene had a slightly higher (but not statistically significant) incidence of ductal carcinoma in situ compared with the tamoxifen arm (2.11 per 1000 versus 1.51 per 1000 ; RR $1.40 ; 95 \%$ CI $0.98-2.00)$. The two study arms were similar in risk for ischemic heart disease, osteoporotic fractures, and stroke. Raloxifene was associated with less morbidity from thromboembolic phenomena and cataracts, and a trend for fewer uterine cancers was also observed in the raloxifene arm. A quality-of-life analysis revealed low symptom severity in both study arms, but slight increases in vasomotor symptoms, leg cramps, and bladder problems were reported in the tamoxifen arm [21].

One theory of breast carcinogenesis proposes that risk of malignant transformation is related to lifetime exposure of breast tissue to cyclic extremes in the levels of circulating hormones. Accordingly, it is postulated that stabilization of estrogen levels will decrease the incidence of mammary neoplasia. Studies of gonadotropin-releasing hormone agonists in conjunction with low-dose hormone replacement therapy are therefore underway as a means of testing this hypothesis, and preliminary results have shown that this approach can successfully decrease mammographic density [22]; however, longer follow-up is needed to evaluate actual chemoprevention efficacy.

Recent data on the efficacy of aromatase inhibitors for adjuvant therapy in breast cancer have revealed that these agents also possess significant chemoprevention activity [23]. Table 1 [17,23-35] summarizes reported data on the risk-reducing strength of various medical therapies.

\section{Surgical risk reduction with prophylactic oophorectomy or prophylactic mastectomy}

Premenopausal prophylactic oophorectomy and prophylactic mastectomy are additional options as surgical strategies for breast cancer risk reduction. Surgical menopause before age 35 years is an established protective factor against breast cancer risk. Availability of BRCA testing has resulted in the identification of women from hereditary breast-ovarian cancer families, and these women are especially motivated to consider prophylactic removal of the ovaries. Published case-control data (Level II evidence) by Rebbeck and colleagues [36] and Kauff and colleagues [37] have confirmed that prophylactic oophorectomy in this setting can decrease breast cancer incidence by approximately $50 \%$. Premature menopause, however, is associated with an increased risk of osteoporosis and atherosclerotic 
cardiovascular disease. Interestingly, the breast cancer protection afforded by prophylactic oophorectomy was not diminished by hormone replacement therapy in the Rebbeck and colleagues [36] study.

Prophylactic mastectomy is a dramatic and extreme maneuver to decrease breast cancer risk, yet only recently has its efficacy in high-risk women been documented. Early reports of prophylactic mastectomy in humans [38,39] demonstrated a $1 \%$ to $2 \%$ failure rate, but these studies were flawed by limited follow-up, and by the inclusion of many women who were probably at low-risk for developing breast cancer. Women at risk for hereditary breast cancer would potentially be most susceptible to a failed prophylactic mastectomy, as in these cases any microscopic amount of residual breast tissue would harbor the germ line predisposition for malignant transformation.

Hartmann and colleagues [40], have made valuable contributions to our understanding of the efficacy of prophylactic mastectomy through their meticulous scrutiny of the Mayo Clinic database. This analysis yielded 639 prophylactic mastectomy patients who had documented increased risk on the basis of family history of breast or ovarian cancer. These high-risk patients were further stratified into very high-risk (214 patients) and moderately high-risk (425 patients) subsets based on extent of family history. Outcome regarding number of subsequent breast cancers occurring among the veryhigh-risk subset was compared with the number of breast cancers developing among the female siblings of these patients. For the moderate-risk patients, efficacy of the prophylactic surgery was evaluated by calculating the number of expected cancers based on summing of the individual Gail model risk estimates for the entire group. Survival analyses were performed by projecting anticipated longevity based on population-based data. With a median follow-up of approximately 14 years, seven breast cancers were detected in the prophylactic mastectomy patients (three in the very-high risk subset and four in the moderate-risk subset) consistent with a $90 \%$ reduction in breast cancer risk and mortality in both categories of high-risk patients.

Subsequent study of the Hartmann database [41] reported results of prophylactic mastectomy in women who were also found to be BRCA mutation carriers, and confirmed an equivalent magnitude of breast cancer risk reduction. Similarly, Meijers-Heijboer and colleagues [42] reported outcome for 76 BRCA-mutation carriers followed prospectively after having undergone prophylactic mastectomy, and found no tumors developing with an average follow-up of nearly 3 years. Hence, reliable evidence does indicate that prophylactic mastectomy will effectively and substantially reduce the incidence of breast cancer in high-risk women, although the protection conferred is not complete.

\section{Summary}

Options for breast cancer risk assessment continue to evolve, and risk reduction strategies are expanding as well. Breast cancer screening and 
diagnostic work-up for abnormalities should always be prioritized, but healthy women also deserve to receive appropriate counseling regarding their level of risk for breast cancer. Referral to genetic counseling services or to a breast specialist with expertise in chemoprevention should be provided as necessary.

\section{References}

[1] Gail MH, Brinton LA, Byar DP, et al. Projecting individualized probabilities of developing breast cancer for white females who are being examined annually. J Natl Cancer Inst 1989; 81(24):1879-86.

[2] Costantino JP, Gail MH, Pee D, et al. Validation studies for models projecting the risk of invasive and total breast cancer incidence. J Natl Cancer Inst 1999;91(18):1541-8.

[3] Bondy ML, Lustbader ED, Halabi S, et al. Validation of a breast cancer risk assessment model in women with a positive family history. J Natl Cancer Inst 1994;86(8):620-5.

[4] Spiegelman D, Colditz GA, Hunter D, et al. Validation of the Gail et al. model for predicting individual breast cancer risk. J Natl Cancer Inst 1994;86(8):600-7.

[5] Rockhill B, Spiegelman D, Byrne C, et al. Validation of the Gail et al. model of breast cancer risk prediction and implications for chemoprevention. J Natl Cancer Inst 2001;93(5): 358-66.

[6] Fabian CJ, Kimler BF, Zalles CM, et al. Short-term breast cancer prediction by random periareolar fine-needle aspiration cytology and the Gail risk model. J Natl Cancer Inst 2000; 92(15):1217-27.

[7] Fabian C. Benign breast tissue sampling for prevention studies. Breast J 2000;6(4):215-9.

[8] Dooley WC, Ljung BM, Veronesi U, et al. Ductal lavage for detection of cellular atypia in women at high risk for breast cancer. J Natl Cancer Inst 2001;93(21):1624-32.

[9] Boyd NF, Lockwood GA, Martin LJ, et al. Mammographic densities and risk of breast cancer among subjects with a family history of this disease. J Natl Cancer Inst 1999;91(16): 1404-8.

[10] Boyd NF, Rommens JM, Vogt K, et al. Mammographic breast density as an intermediate phenotype for breast cancer. Lancet Oncol 2005;6(10):798-808.

[11] Key T, Appleby P, Barnes I, et al. Endogenous sex hormones and breast cancer in postmenopausal women: reanalysis of nine prospective studies. J Natl Cancer Inst 2002;94(8): 606-16.

[12] Cauley JA, Lucas FL, Kuller LH, et al. Elevated serum estradiol and testosterone concentrations are associated with a high risk for breast cancer. Study of Osteoporotic Fractures Research Group. Ann Intern Med 1999;130(4 Pt 1):270-7.

[13] Cummings SR, Lee JS, Lui LY, et al. Sex hormones, risk factors, and risk of estrogen receptor-positive breast cancer in older women: a long-term prospective study. Cancer Epidemiol Biomarkers Prev 2005;14(5): 1047-51.

[14] Chen J, Pee D, Ayyagari R, et al. Projecting absolute invasive breast cancer risk in white women with a model that includes mammographic density. J Natl Cancer Inst 2006; 98(17):1215-26.

[15] Barlow WE, White E, Ballard-Barbash R, et al. Prospective breast cancer risk prediction model for women undergoing screening mammography. J Natl Cancer Inst 2006;98(17): 1204-14.

[16] Bondy ML, Newman LA. Assessing breast cancer risk: evolution of the Gail model. J Natl Cancer Inst 2006;98(17):1172-3.

[17] Fisher B, Costantino JP, Wickerham DL, et al. Tamoxifen for prevention of breast cancer: report of the National Surgical Adjuvant Breast and Bowel Project P-1 Study. J Natl Cancer Inst 1998;90(18):1371-88. 
[18] King MC, Wieand S, Hale K, et al. Tamoxifen and breast cancer incidence among women with inherited mutations in BRCA1 and BRCA2: National Surgical Adjuvant Breast and Bowel Project (NSABP-P1) Breast Cancer Prevention Trial. JAMA 2001;286(18):2251-6.

[19] Vogel VG, Costantino JP, Wickerham DL, et al. Effects of tamoxifen vs raloxifene on the risk of developing invasive breast cancer and other disease outcomes: the NSABP Study of Tamoxifen and Raloxifene (STAR) P-2 trial. JAMA 2006;295(23):2727-41.

[20] Land SR, Wickerham DL, Costantino JP, et al. Patient-reported symptoms and quality of life during treatment with tamoxifen or raloxifene for breast cancer prevention: the NSABP Study of Tamoxifen and Raloxifene (STAR) P-2 trial. JAMA 2006;295(23):2742-51.

[21] Land S. Quality-of-life valuations of advanced breast cancer by New Zealand women. Pharmacoeconomics 2006;24(4):415-6 [author reply: 416-7].

[22] Gram IT, Ursin G, Spicer DV, et al. Reversal of gonadotropin-releasing hormone agonist induced reductions in mammographic densities on stopping treatment. Cancer Epidemiol Biomarkers Prev 2001;10(11):1117-20.

[23] Baum M, Budzar AU, Cuzick J, et al. Anastrozole alone or in combination with tamoxifen versus tamoxifen alone for adjuvant treatment of postmenopausal women with early breast cancer: first results of the ATAC randomised trial. Lancet 2002;359(9324):2131-9.

[24] Cuzick J, Powles T, Veronesi U, et al. Overview of the main outcomes in breast-cancer prevention trials. Lancet 2003;361(9354):296-300.

[25] Powles T, Eeles R, Ashley S, et al. Interim analysis of the incidence of breast cancer in the Royal Marsden Hospital tamoxifen randomised chemoprevention trial. Lancet 1998; 352(9122):98-101.

[26] Veronesi U, Maisonneuve P, Rotmensz N, et al. Italian randomized trial among women with hysterectomy: tamoxifen and hormone-dependent breast cancer in high-risk women. J Natl Cancer Inst 2003;95(2):160-5.

[27] Veronesi U, Maisonneuve P, Sacchini V, et al. Tamoxifen for breast cancer among hysterectomised women. Lancet 2002;359(9312):1122-4.

[28] Veronesi U, Maisonneuve P, Costa A, et al. Prevention of breast cancer with tamoxifen: preliminary findings from the Italian randomised trial among hysterectomised women. Italian Tamoxifen Prevention Study. Lancet 1998;352(9122):93-7.

[29] First results from the International Breast Cancer Intervention Study (IBIS-I): a randomised prevention trial. Lancet 2002;360(9336):817-24.

[30] Cauley JA, Norton L, Lippman ME, et al. Continued breast cancer risk reduction in postmenopausal women treated with raloxifene: 4-year results from the MORE trial. Multiple Outcomes of Raloxifene Evaluation. Breast Cancer Res Treat 2001;65(2):125-34.

[31] Veronesi U, De Palo G, Marubini E, et al. Randomized trial of fenretinide to prevent second breast malignancy in women with early breast cancer. J Natl Cancer Inst 1999;91(21): $1847-56$.

[32] Nagata C, Takatsuka N, Inaba S, et al. Effect of soymilk consumption on serum estrogen concentrations in premenopausal Japanese women. J Natl Cancer Inst 1998;90(23): $1830-5$.

[33] Martino S, Cauley JA, Barrett-Connor E, et al. Continuing outcomes relevant to Evista: breast cancer incidence in postmenopausal osteoporotic women in a randomized trial of raloxifene. J Natl Cancer Inst 2004;96(23):1751-61.

[34] Vogel VG, Costantino JP, Wickerham DL, et al. The study of tamoxifen and raloxifene: preliminary enrollment data from a randomized breast cancer risk reduction trial. Clin Breast Cancer 2002;3(2):153-9.

[35] Tamoxifen for early breast cancer: an overview of the randomised trials. Early Breast Cancer Trialists' Collaborative Group. Lancet 1998;351(9114):1451-67.

[36] Rebbeck TR, Levin AM, Eisen A, et al. Breast cancer risk after bilateral prophylactic oophorectomy in BRCA1 mutation carriers. J Natl Cancer Inst 1999;91(17):1475-9.

[37] Kauff ND, Satagopan JM, Robson ME, et al. Risk-reducing salpingo-oophorectomy in women with a BRCA1 or BRCA2 mutation. N Engl J Med 2002;346(21):1609-15. 
[38] Pennisi VR, Capozzi A. Subcutaneous mastectomy data: a final statistical analysis of 1500 patients. Aesthetic Plast Surg 1989;13(1):15-21.

[39] Woods JE, Meland NB. Conservative management in full-thickness nipple-areolar necrosis after subcutaneous mastectomy. Plast Reconstr Surg 1989;84(2):258-64 [discussion: 265-6].

[40] Hartmann LC, Schaid DJ, Woods JE, et al. Efficacy of bilateral prophylactic mastectomy in women with a family history of breast cancer. N Engl J Med 1999;340(2):77-84.

[41] Hartmann LC, Sellers TA, Schaid DJ, et al. Efficacy of bilateral prophylactic mastectomy in BRCA1 and BRCA2 gene mutation carriers. J Natl Cancer Inst 2001;93(21):1633-7.

[42] Meijers-Heijboer H, van Geel B, van Putten WL, et al. Breast cancer after prophylactic bilateral mastectomy in women with a BRCA1 or BRCA2 mutation. N Engl J Med 2001; 345(3):159-64. 